\title{
Glacitektonika krawędziowa w dolinie Wisły a dynamika wód podziemnych
}

\section{Connection between glacitectonic forms and groundwater flow in the Vistula River Valley}

\author{
Filip Bujakowski ${ }^{1}$, Piotr Ostrowski ${ }^{1}$, Łukasz Sopel ${ }^{1,2}$, Hanna Złotoszewska-Niedziałek ${ }^{1}$ \\ ${ }^{1}$ Katedra Geoinżynierii, Szkoła Główna Gospodarstwa WiejskiegowWarszawie, filip_bujakowski@sggw.pl \\ ${ }^{2}$ Hydroconsult Sp. z o.o., Warszawa
}

\begin{abstract}
Zarys treści: Wypiętrzenia glacitektoniczne zbudowane z iłów plioceńskich spotykane w strefach krawędziowych dolin rzecznych tworzą często pionowe, praktycznie nieprzepuszczalne bariery, ograniczające kontakt hydrauliczny struktur wodonośnych wysoczyzny z aluwialnym poziomem wód podziemnych w dolinie. W artykule przedstawiono znaczenie wypiętrzenia strukturalnego Wólki Mlądzkiej w kształtowaniu warunków krążenia wód podziemnych piętra czwartorzędowego oraz jego roli jako naturalnej geologicznej bariery ograniczającej rozprzestrzenianie się zanieczyszczeń. Rozwiązanie postawionego w pracy problemu badawczego wymagało zastosowania metody modelowania numerycznego. Do obliczeń numerycznych przepływu wody podziemnej użyto aplikacji Modflow 2005 wchodzącej w skład pakietu Visual Modflow 2009.
\end{abstract}

Słowa kluczowe: wypiętrzenie strukturalne, warunki hydrogeologiczne, wody podziemne, obliczenia numeryczne

\begin{abstract}
Glacitectonic landforms (composite ridges) composed of the Pliocene lacoustrine clays can be found under the Pleistocene glacial sediments in the edge zones of the large river valleys in Polish Lowlands. These glacitectonic structures create a barrier for the hydraulic contact between the aquifers of the alluvial layers in the river valley and the permeable layer on the morainic plateau (high plain). The paper describes the impact of glacitectonic structure of Wólka Mlądzka (25 km SW from Warsaw) on a groundwater dynamics of Quartenary aquifer with a specific emphasis on reducing of pollutant migration. To reach aim of the study it was necessary to involve numerical modelling of groundwater flow using Modflow 2005 from the Visual Modflow 2009 package.
\end{abstract}

Key words: glacitectonic composite ridges, hydrogeological conditions, groundwater, numerical modelling

\section{Wstęp}

Glacitektoniczne fałdy zbudowane z iłów plioceńskich, nadbudowanych miejscami utworami zwałowymi, występują powszechnie w strefach krawędziowych dolin Wisły, Odry czy Prosny (Różycki 1972, Brykczyński 1982, Falkowski 1999). Wypiętrzenia glacitektoniczne spotykane w strefach krawędziowych dolin tworzą często pionowe, praktycznie nieprzepuszczalne bariery (Aber, Ber 2007), ograniczające kontakt hydrauliczny struktur wodonośnych wysoczyzny z aluwialnym poziomem wód podziemnych w dolinach. Obecność takich struktur wpływa na ograniczanie możliwości rozprzestrzeniania się za- nieczyszczeń, które pochodzić mogą z obiektów zlokalizowanych na obszarach wysoczyznowych.

Specyficznym typem strukturalnej bariery geologicznej jest wypiętrzenie Wólki Mlądzkiej. Według Baranieckiej (1976) powstanie wypiętrzenia należy wiązać z impulsami tektonicznymi, które miały miejsce na przełomie zlodowacenia południowopolskiego i interglacjału mazowieckiego, natomiast górne części fałdów zostały zaburzone glacitektonicznie przez lądolód środkowopolski. Obecność struktury Wólki Mlądzkiej wpływa zarówno na regionalne, jak i lokalne warunki krążenia wód podziemnych (Złotoszewska-Niedziałek 2007, 2012). Narzędziem do analizy kierunków przepływu wód podziemnych ba- 
danego rejonu może być metoda modelowania matematycznego.

Celem badań jest określenie znaczenia wypiętrzenia strukturalnego Wólki Mlądzkiej w kształtowaniu warunków krążenia wód podziemnych piętra czwartorzędowego oraz jego rola jako naturalnej geologicznej bariery ograniczającej rozprzestrzenianie się zanieczyszczeń. W ramach badań przeprowadzono kwerendę materiałów archiwalnych głównie z zasobów PIG-PIB (Baraniecka 1976, Sarnacka 1976, Mianowski 1997, Perek 1997, Baza 2014). Wykonano także pomiary głębokości zwierciadła wód podziemnych w piezometrach oraz studniach. Rozwiązanie postawionego $\mathrm{w}$ pracy problemu badawczego wymagało zastosowania metody modelowania numerycznego.

Obszar badań zlokalizowany jest w powiecie otwockim, województwie mazowieckim. Jego powierzchnia wynosi $191 \mathrm{~km}^{2}$. Granicę zachodnią terenu stanowi rzeka Wisła, północną i wschodnią rzeka Świder, południowa natomiast biegnie wzdłuż drogi krajowej nr 50 (ryc. 1).

\section{Warunki geologiczne i hydrogeologiczne}

Analizowany obszar położony jest w obrębie południowo-wschodnich obrzeży Kotliny Warszawskiej. Zasadniczymi formami rzeźby są tu: wysoczyzna - północna część Równiny Garwolińskiej oraz Dolina Środkowej Wisły (Kondracki 2001). Powierzchnię Równiny Garwolińskiej budują osady zlodowaceń środkowopolskich. Wysoczyzna przedstawia się jako dość monotonna, płaska powierzchnia, o niewielkim spadku w kierunku północno-zachodnim, której wysokości bezwzględne wynoszą 125-140 m n.p.m. Wysoczyzna morenowa rozcięta jest licznymi formami dolinnymi (suche doliny), które są śladami porzuconych przepływów rzecznych. Ich rozwój zakończył się w czasie zlodowacenia północnopolskiego. Omawiany obszar należy uznać za nadmiernie uwilgotniony, czego przyczyną jest płytkie zaleganie utworów słabo przepuszczalnych (mineralnych i organicznych). Wysoczyzna rozcięta jest doliną rzeki Świder.

Dolina Wisły ograniczona jest na ogół łagodnymi zboczami Wysoczyzny Garwolińskiej. Miejscami krawędź wysoczyzny nie zaznacza się wyraźnie w morfologii, między innymi ze względu na liczne występujące u jej podnóża

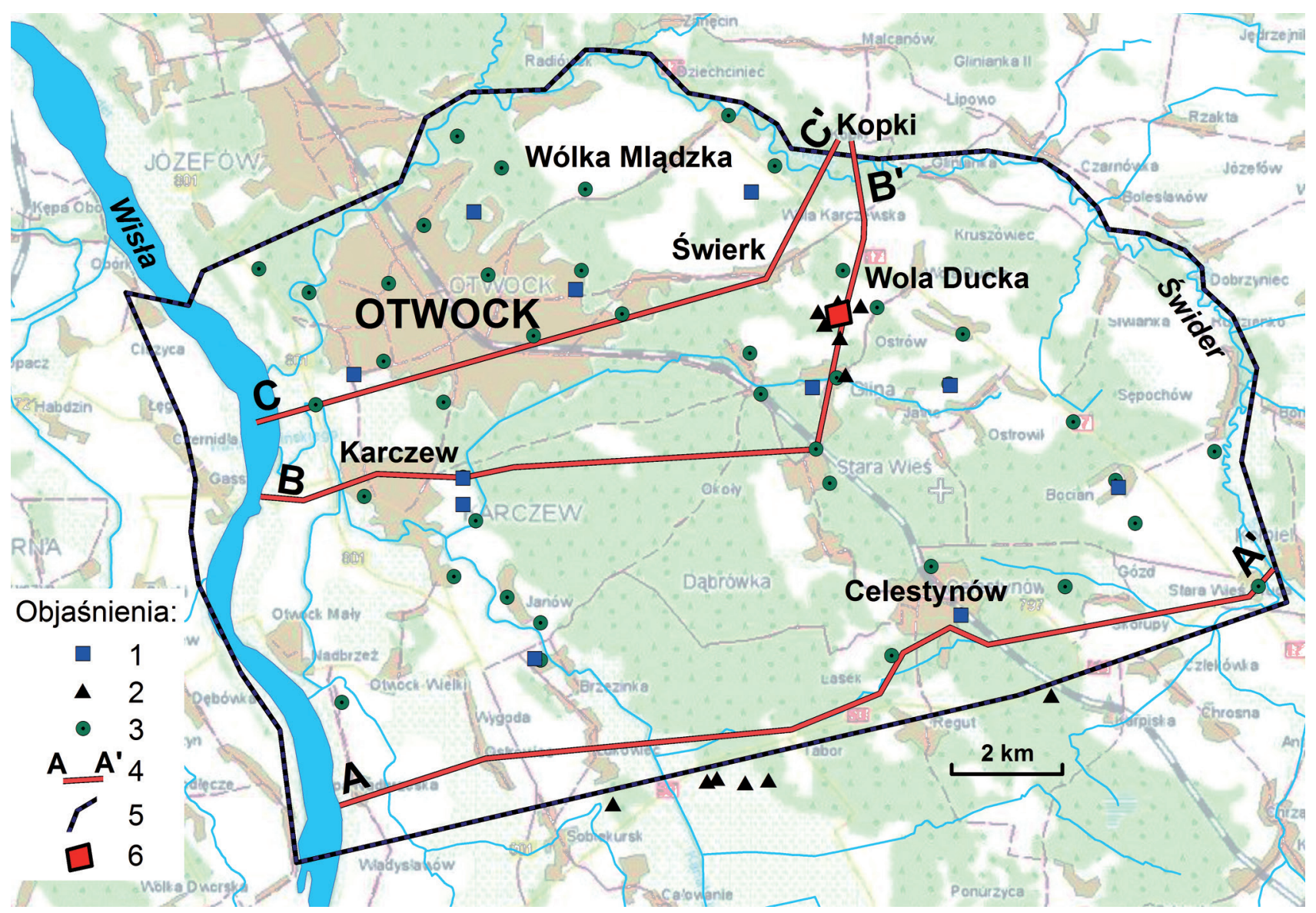

Ryc. 1. Położenie obszaru badań

1 - ujęcia wód podziemnych, 2 - piezometry, 3 - punkty pomiaru zwierciadła wody podziemnej, 4 - linie przekrojów hydrogeologicznych, 5 - granica obszaru badań, 6 - składowisko odpadów

Fig. 1. Location of the research area

1 - groundwater intakes, 2 - observation Wells, 3 - points of groundwater table measurement, 4 - line of hydrogeological cross-sections study area, 5 - study area, 6 - landfill site 


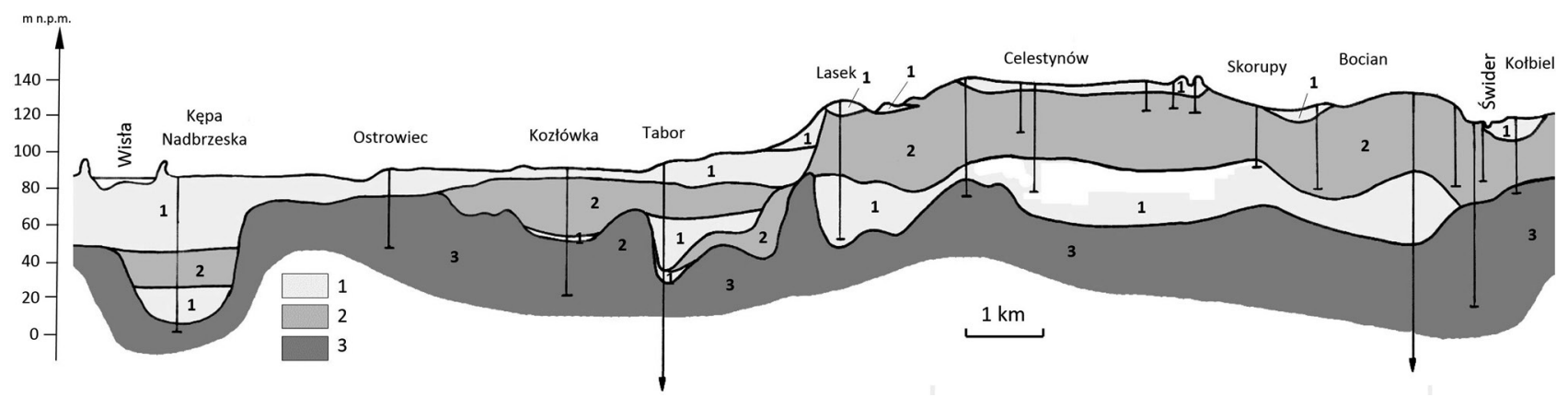

Ryc. 2. Schematyczny przekrój hydrogeologiczny A-A' w rejonie badań (na podstawie przekroju geologicznego Baraniecka 1976) 1 - utwory przepuszczalne (piaski, żwiry), 2 - utwory słabo przepuszczalne (gliny zwałowe, mułki i pyły), 3 - utwory praktycznie nieprzepuszczalne (iły)

Fig. 2. Hydrogeological cross section A-A' in the study area (on the basis of geological cross-section by Baraniecka 1976) 1 - rocks of good permeability (gravels, sands), 2 - rocks of low permeability (till clay, silt), 3 - rocks of none permeability (clay)

wydmy (Otwock, Lasek). Zbocze doliny urozmaicone jest wcięciami erozyjnymi drobnych cieków i wąwozów. Dno doliny Wisły wyściełają utwory aluwialne i organiczne uformowane w system teras. Baraniecka (1976) wyróżnia tu trzy terasy nadzalewowe (otwocką, karczewską, janowską) z okresu zlodowacenia północnopolskiego oraz terasę niską - zalewową, którą rzeka uformowała w holocenie. Powierzchnia dna doliny leży na wysokości od około $89 \mathrm{~m}$ n.p.m. (terasa zalewowa) do około 100 m n.p.m. na terasie otwockiej. Obszar ten budują głównie utwory korytowe reprezentowane przez piaski drobno- i średnioziarniste z pojedynczymi otoczakami i żwirami o miąższości od kilku do kilkunastu metrów, na których powierzchni występują osady facji powodziowej - mady o niewielkiej miąższości (1-2 m) oraz namuły i piaski humusowe. Na powierzchni teras oraz u podnóża wysoczyzny występują wydmy i pola piasków eolicznych. Teren w rejonie badań odwadniany jest za pośrednictwem drobnych strug i rowów melioracyjnych przez rzekę Świder i Wisłę.

Analizowany poligon badawczy znajduje się w Niecce Mazowieckiej, która jest regionem hydrostrukturalnym obejmującym kenozoiczną formację wodonośną składającą się z dwóch pięter wodonośnych: trzeciorzędowego i czwartorzędowego (Kleczkowski 1990, Malinowski 1991). Ze względu na rozwiązanie problemu badawczego najistotniejsza jest charakterystyka hydrogeologiczna utworów czwartorzędowych i związanych z nimi poziomów wodonośnych. Piętro to izolowane jest od niżej leżących wód podziemnych występujących w osadach trzeciorzędowych (mioceńskich i oligoceńskich) kompleksem utworów iłów plioceńskich o miąższości od 70 do $150 \mathrm{~m}$.

B

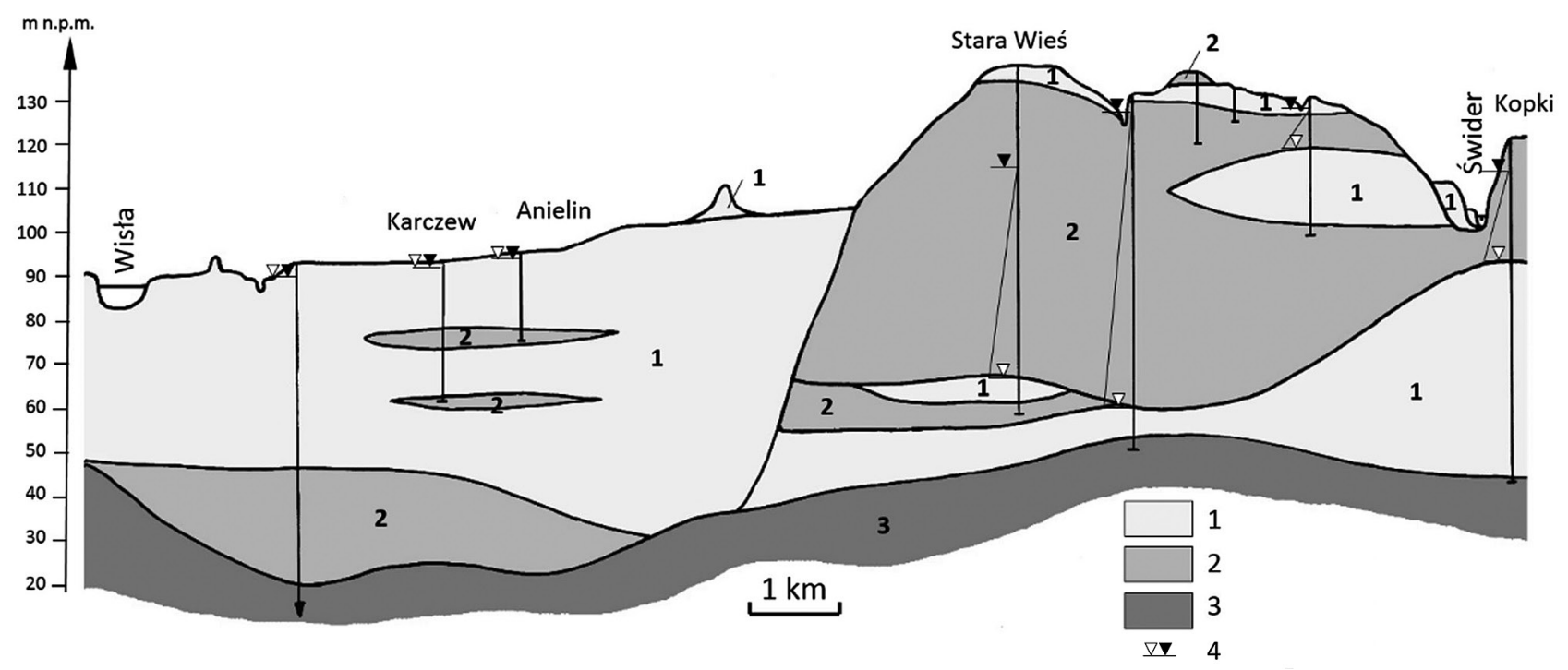

Ryc. 3. Schematyczny przekrój hydrogeologiczny B-B' przecinający strefę depresji podłoża czwartorzędowego

1 - utwory przepuszczalne (piaski, żwiry), 2 - utwory słabo przepuszczalne (gliny zwałowe, mułki i pyły), 3 - utwory praktycznie nieprzepuszczalne (iły), 4 - zwierciadło wody podziemnej

Fig. 3. Hydrogeological cross section B-B' intersecting the depression of Quaternary bed

1 - rocks of good permeability (gravels, sands), 2 - rocks of low permeability (till clay, silt), 3 - rocks of none permeability (clay), 4 - groundwater table 
Na podstawie danych archiwalnych PIG-PIB i literatury (Baraniecka 1976, Malinowski 1991) na analizowanym terenie można mówić o istnieniu dwóch układów krążenia:

- strukturze Wólki Mlądzkiej - obszarze wypiętrzenia strukturalnego,

- strukturze hydrogeologicznej tworzącej system wodonośny zasilany wodami opadowymi oraz poprzez dopływ lateralny z obszarów sąsiednich, którego strefę drenażu stanowi koryto rzeki Wisły (dolina Wisły).

Podłoże utworów czwartorzędowych stanowią zaburzone glacitektonicznie osady plioceńskie, które reprezentowane są przez kompleks iłów pstrych z soczewkami i warstwami piasków. Deniwelacje położenia stropu iłów przekraczają 100 m (Baraniecka 1976) (ryc. 2-4). W obrębie wypiętrzenia strukturalnego Wólki Mlądzkiej wyróżniono trzy równolegle przebiegające elewacje iłów plioceńskich o kierunku NW-SE. W rejonie badań występują elewacje: Świerk-Wola Ducka oraz Kopki-Kruszowiec (ryc. 4). W granicach wspomnianych elewacji strop pliocenu leży na wysokości 100-130 m n.p.m. Pomiędzy elewacjami znajduje się on na wysokości 30-45 m n.p.m. (ryc. 2-4).

Na terenie badań, w obrębie zaburzonego kompleksu glin zwałowych, mułków i iłów, występują warstwy wodonośne w formie soczew i przewarstwień - najczęściej o niskich parametrach hydrogeologicznych. Miąższość osadów czwartorzędowych waha się od 0 na wypiętrzeniu strukturalnym - Wólce Mlądzkiej do około $100 \mathrm{~m}$ na pozostałym obszarze. W strefie przypowierzchniowej zalegają osady przepuszczalne wykształcone w postaci piasków średnio- i drobnoziarnistych oraz piasków gliniastych o miąższości od 1 do $4 \mathrm{~m}$. Występowanie wody podziemnej związane jest tu zazwyczaj z osadami wypełniającymi dawne drogi powierzchniowego odpływu w obrębie wysoczyzny polodowcowej. Zwierciadło wód podziemnych ma charakter swobodny i jego położenie uzależnione jest od wielkości infiltracji opadów. Wody z tych warstw eksploatowane są tylko lokalnie do celów gospodarczych ze względu na ich małe zasoby i złą jakość. Poniżej leży ciągły kompleks osadów słabo przepuszczalnych: pyły, gliny piaszczyste i pylaste, gliny

\section{C}

m n.p.m.

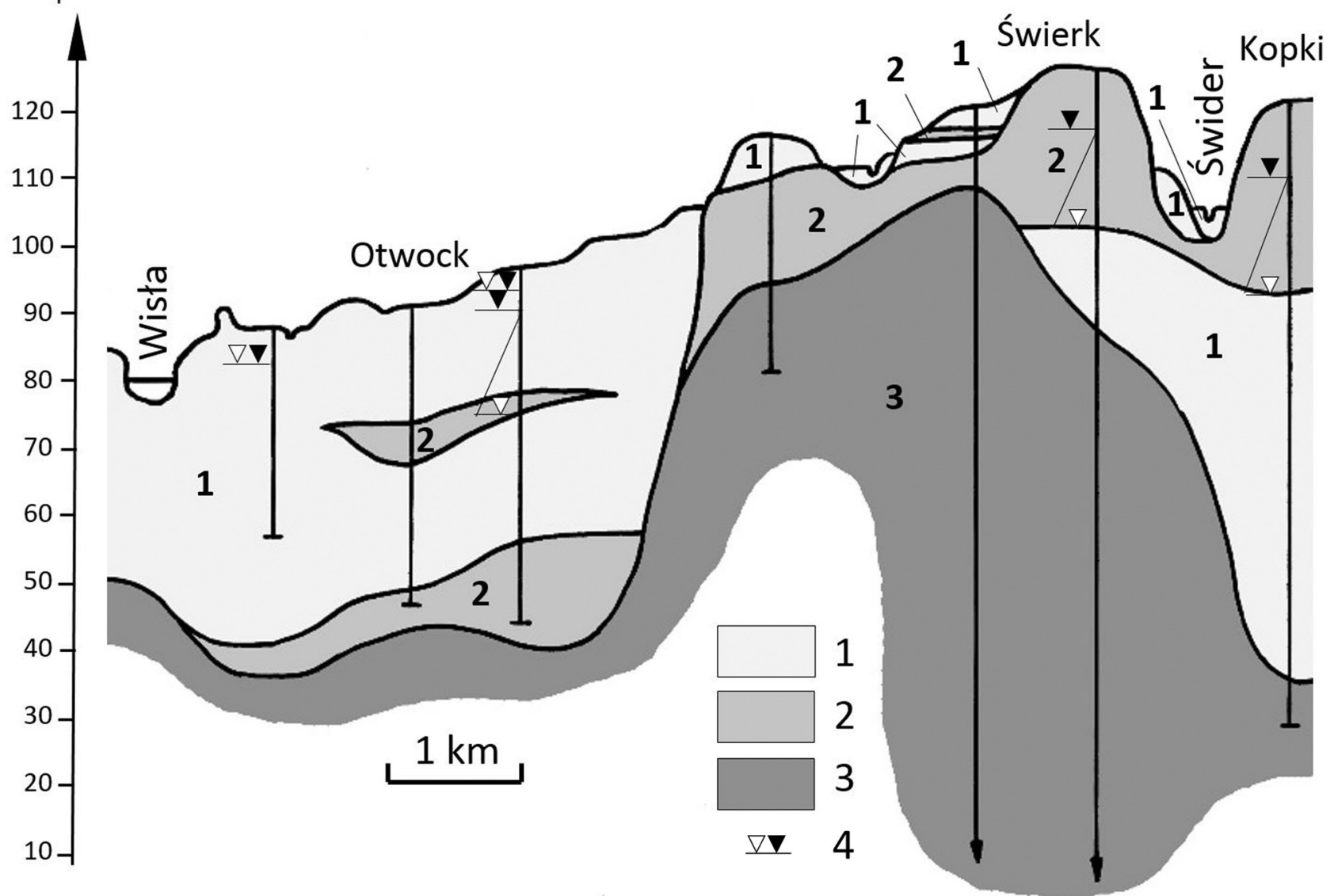

Ryc. 4. Schematyczny przekrój hydrogeologiczny C-C'przecinający elewację Świerk-Wola Ducka

1 - utwory przepuszczalne (piaski, żwiry), 2 - utwory słabo przepuszczalne (gliny zwałowe, mułki i pyły), 3 - utwory praktycznie nieprzepuszczalne (iły), 4 - zwierciadło wody podziemnej

Fig. 4. Hydrogeological cross section C-C' intersecting Świerk-Wola Ducka elevation

1 - rocks of good permeability (gravels, sands), 2 - rocks of low permeability (till clay, silt), 3 - rocks of none permeability (clay), 4 - groundwater table 
z otoczakami, których całkowita miąższość waha się od 5 do $70 \mathrm{~m}$. W obrębie tych utworów występują warstwy wodonośne zbudowane z piasków drobno- i średnioziarnistych oraz żwirów o miąższości od 3 do $20 \mathrm{~m}$.

Utwory te charakteryzują się wartościami współczynnika filtracji $\mathrm{k}=5,3-8,6 \times 10^{-5} \mathrm{~m} \mathrm{~s}^{-1}$, a wydatek pojedynczych otworów eksploatacyjnych waha się od 18 do $22 \mathrm{~m}^{3} \mathrm{~h}^{-1}$ (Złotoszewska-Niedziałek 2007, 2012). Wody podziemne zasilane są pośrednio poprzez przesączanie wód gruntowych i opadowych. Miejscami, w obrębie wysoczyzny, w obniżeniach stropu iłów plioceńskich występuje ciągła warstwa wodonośna zbudowana z osadów piaszczystych, której miąższość waha się od kliku do 50 m (ryc. 2, 4). Utwory te charakteryzują się wartościami współczynnika filtracji $\mathrm{k}=2,1-9,3 \times 10^{-5} \mathrm{~m} \mathrm{~s}^{-1}$, a wydatek pojedynczych otworów eksploatacyjnych waha się od 18,5 do $80 \mathrm{~m}^{3} \mathrm{~h}^{-1}$. Poziom ten zasilany jest prawdopodobnie z SE ku NW, wzdłuż przypuszczalnego przebiegu obniżeń stropu osadów plioceńskich (Baraniecka 1976).

W strefie doliny poziom wodonośny związany jest $\mathrm{z}$ osadami interglacjału mazowieckiego, interstadiału Bugo-Narwi, interglacjału eemskiego, zlodowacenia Wisły i holocenu. Budują go piaski i żwiry rzeczne z otoczakami. Całkowita miąższość osadów wodonośnych waha się od kilkunastu do około $40 \mathrm{~m}$. Współczynniki filtracji tych utworów mieszczą się w granicach $1,5-5,4 \times 10^{-4} \mathrm{~m} \mathrm{~s}^{-1}$ (Małecki i in. 2006). Zwierciadło ma charakter swobodny i leży na głębokości od 1 do $5 \mathrm{~m}$ p.p.t. W obrębie utworów wodonośnych występują przewarstwienia osadów słabo przepuszczalnych, które powodują lokalne napięcie zwierciadła wody podziemnej. Poziom zasilany jest bezpośrednio poprzez infiltrację opadów atmosferycznych.

\section{Konstrukcja modelu numerycznego}

W identyfikacji systemów krążenia wód gruntowych na obszarze badań, w tym warunków ich zasilania i drenażu oraz bilansu przepływu, wykorzystano wyniki modelowania matematycznego filtracji wód podziemnych. Pierwszym etapem prac było odzwierciedlenie na modelu warunków geologicznych i hydrogeologicznych występujących aktualnie. Do badań modelowych zastosowano pakiet oprogramowania Visual MODFLOW (ver. 2009.1). Jest on narzędziem służącym do symulowania ustalonych i nieustalonych warunków przepływu wód podziemnych, zachodzących w kompleksach składających się z jednego bądź wielu poziomów wodonośnych, także połączonych ze sobą hydraulicznie za pomocą kontaktów bezpośrednich lub pośrednich, poprzez warstwy rozdzielające. Visual MODFLOW rozwiązuje zadanie przepływu wód podziemnych metodą różnic skończonych (Małecki i in. 2006).

$\mathrm{Na}$ terenie badań dyskretne odwzorowanie przestrzeni modelu koncepcyjnego w płaszczyźnie poziomej (XY) wykonano za pomocą regularnej siatki kwadratowej. Siatka dyskretyzacyjna obszaru wyznaczonego do badań modelowych składała się z 500 kolumn i 500 wierszy. Bryła modelu osadzona została w PUWG 1992. Dyskretyzacja przestrzeni względem osi pionowej (Z) odbywa się najczęściej w celu uwzględnienia niejednorodności warstwy, poprzez jej podział na podwarstwy o różnych parametrach filtracyjnych. W przypadku modelowanego obszaru zastosowano schemat siedmiowarstwowy. Strop pierwszej warstwy równy jest rzędnej terenu. Rzeźba terenu na potrzeby modelu pozyskana została z numerycznego modelu terenu (Centralny Ośrodek Dokumentacji Geodezyjnej i Kartograficznej). Strop kolejnych warstw odwzorowano zgodnie z przyjętą na potrzeby modelu schematyzacją warunków hydrogeologicznych przygotowaną na podstawie wykonanych przekrojów geologicznych. $\mathrm{W}$ modelowaniu przepływu wód gruntowych w warunkach filtracji ustalonej konieczne do rozwiązania układu równań różnicowych jest określenie warunków brzegowych. Warunki te dają możliwość przedstawienia relacji, jak również uwzględnienia w obliczeniach wymiany wód między wydzielonym systemem a otoczeniem. W konstrukcji modelu zastosowano warunki brzegowe I, II i III rodzaju. Warunkiem I rodzaju (wariant Constant Head) odwzorowano wysokość hydrauliczną w transekcie wzdłuż południowej granicy obszaru oraz w korycie rzeki Wisły. Niezerowy warunek II rodzaju realizowany jest z wykorzystaniem dwóch modułów pakietu MODFLOW Recharge i Well. W przedmiotowym modelu moduł Well zastosowano poprzez wprowadzenie otworów eksploatacyjnych, modułem Recharge natomiast zasymulowano infiltrację efektywną. Warunkiem III rodzaju zasymulowana została relacja modelowanego systemu z wodami rzeki Świder (wariant River) - patrz rycina 5.

Dla tak zdefiniowanych warunków geologicznych i hydrogeologicznych omawianego obszaru przyjmuje się następujące szczegółowe założenia modelowe:

- proces filtracji ma charakter ustalony,

- wartości przewodnictwa wodnego są stałe w czasie,

- rozkład parametrów przestrzennych modelu oraz niejednorodność warstw uwzględnia się poprzez zróżnicowanie parametrów wewnątrz sieci dyskretyzacyjnej.

Stworzenie numerycznego modelu przepływu wód podziemnych wymaga wprowadzenia wartości parametrów hydrogeologicznych opisujących modelowany obszar. Podstawowym parametrem wprowadzanym do modelu jest współczynnik filtracji k, charakteryzujący wodoprzepuszczalność modelowanego ośrodka. W przedstawioanym modelu parametr ten został zróżnicowany w obrębie poszczególnych warstw (ryc. 5).

Do oceny zgodności obliczonych wartości wysokości hydraulicznej z wartościami oszacowanymi podczas prac terenowych zastosowano analizę błędów. Weryfikacja modelu została przeprowadzona w oparciu o następujące typy błędów (McDonald, Herbaugh 1988):

błąd średni (residual mean):

$$
=\frac{1}{n}\left(h_{0}-h_{p}\right)_{i}
$$




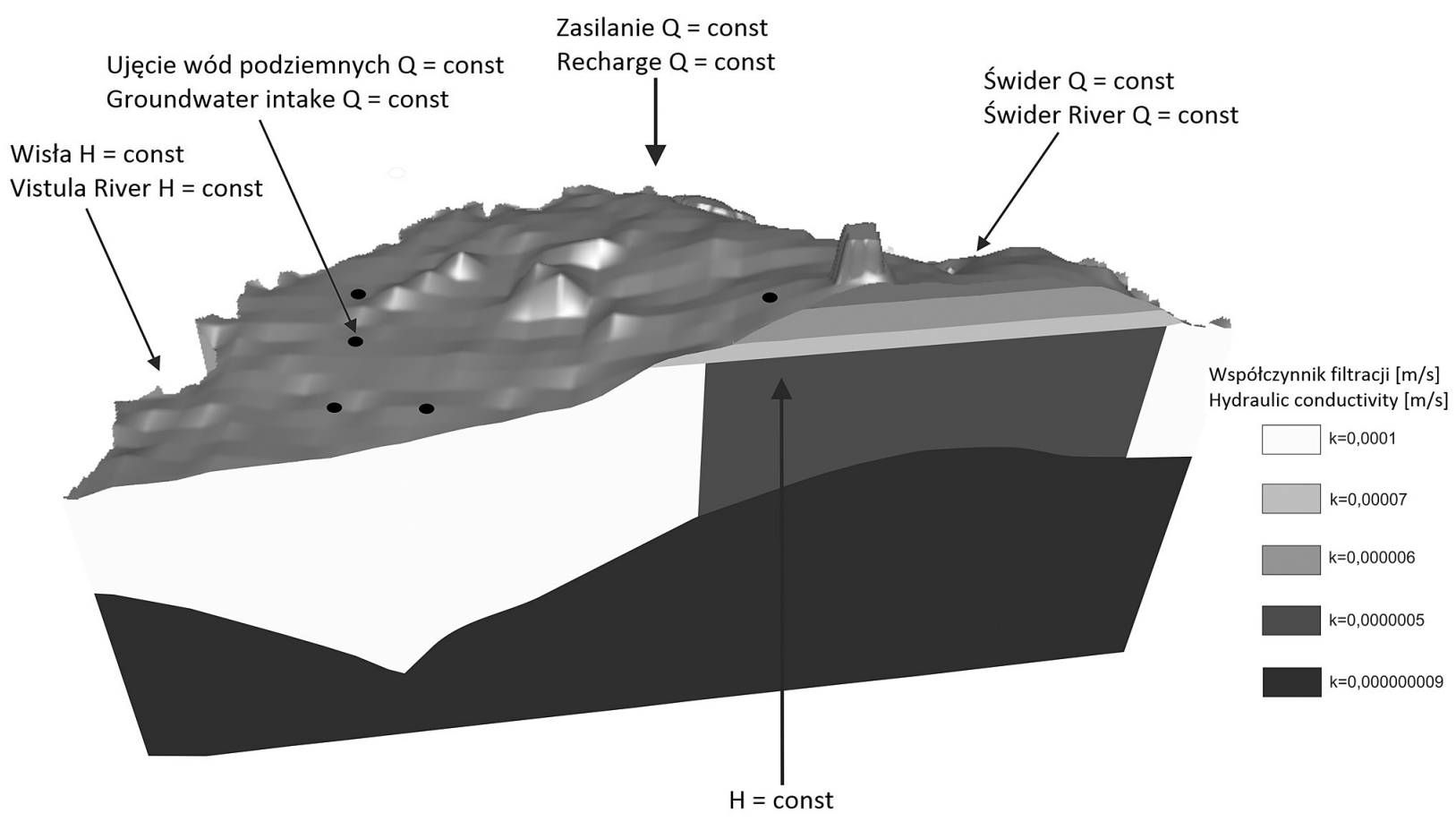

Ryc. 5. Bryła modelu numerycznego i przyjęte warunki brzegowe

Fig. 5. Block of numerical model and boundary conditions

błąd średni absolutny (absolute residual mean)

$$
=\frac{1}{n} \sum_{i=1}^{\mathrm{n}}\left|h_{0-\mathrm{h}_{p}}\right|_{i}
$$

standardowy błąd estymacji (root mean squared)

$$
R M S=\frac{1}{n} \sqrt{\sum_{i=1}^{n}\left(h_{0}-h_{p}\right)_{i}}
$$

znormalizowany błąd RMS ( $n R M S$ )

$$
n R M S=\frac{R M S}{\left(h_{p}\right)_{\max }-\left(h_{0}\right)_{\min }}
$$

gdzie:

$\mathrm{h}_{\mathrm{p}}$ - pomierzona wartość wysokości hydraulicznej [m],

$\mathrm{h}_{0}^{\mathrm{p}}$ - obliczona wartość wysokości hydraulicznej [m],

$\left(\mathrm{h}_{\mathrm{p}}\right)_{\max }$ - maksymalna pomierzona wartość wysokości hydraulicznej [m],

$\left(\mathrm{h}_{0}\right)_{\min }-$ minimalna obliczona wartość wysokości hydraulicznej [m],

$\mathrm{n}$ - liczba węzłów obliczeniowych,

i - numer węzła.

Głównym celem kalibracji modelu było uzyskanie największej zgodności pomiędzy stanem hydrodynamicznym strumienia wód podziemnych zarejestrowanym podczas prac terenowych a stanem otrzymanym w wyniku symulacji komputerowej. Wykres dopasowania pomierzonych oraz obliczonych wysokości hydraulicznych na omawianym obszarze, jak również oszacowane przez program MODFLOW błędy przedstawiono na rycinie 6.

\section{Wyniki obliczeń i ich analiza}

Zgodnie z wynikami badań modelowych zasoby wód podziemnych kształtowane są głównie przez zasilanie lateralne z południowej i wschodniej części obszaru. Wielkość zasilania infiltracyjnego modelowanego terenu wynosi średnio $2000 \mathrm{~m}^{3} \mathrm{~d}^{-1}$, co stanowi zaledwie 3\% całkowitego zasilania. Natomiast w rejonie wypiętrzenia utworów słabo przepuszczalnych jest składową dominującą. Zasilanie infiltracyjne oraz pozostałe elementy składowe przychodów w bilansie przepływu równoważone są w głównej mierze poprzez odpływ do cieków powierzchniowych. Wielkość drenażu rzecznego (Wisła, Świder) wynosi około $40000 \mathrm{~m}^{3} \mathrm{~d}^{-1}$, co stanowi około $50 \%$ całkowitego odpływu. Świadczy to o dużej zależności oraz znaczącej roli wód powierzchniowych w krążeniu wód podziemnych na omawianym terenie.

$\mathrm{Na}$ obszarze występowania elewacji iłów plioceńskich zaznacza się wyraźnie strefa wododziałowa. Elewacja tworzy barierę dla przepływu wód podziemnych. Na zachód od niej bazę drenażową stanowi rzeka Wisła, na wschód zaś rzeka Świder (ryc. 7, 8). W strefie wododziałowej, ze względu na występowanie znacznej miąższości osadów słabo przepuszczalnych w występujących lokalnie przewarstwieniach piaszczystych, wody podziemne cechuje duże ciśnienie hydrostatyczne. Przewarstwienia te w większości przypadków są odizolowane od wodonośnych kompleksów dolinnych, w związku z czym nie występują znaczne przepływy lateralne. Brak przepływu w połączeniu z jedynie infiltracyjnym zasilaniem sprawia, że stagnujące $w$ soczewach wody mogą być podatne na kumulacje zanieczyszczeń. Sytuacja taka wystąpić może w strefach o zwiększonych przewodnościach skał nadkładu. 


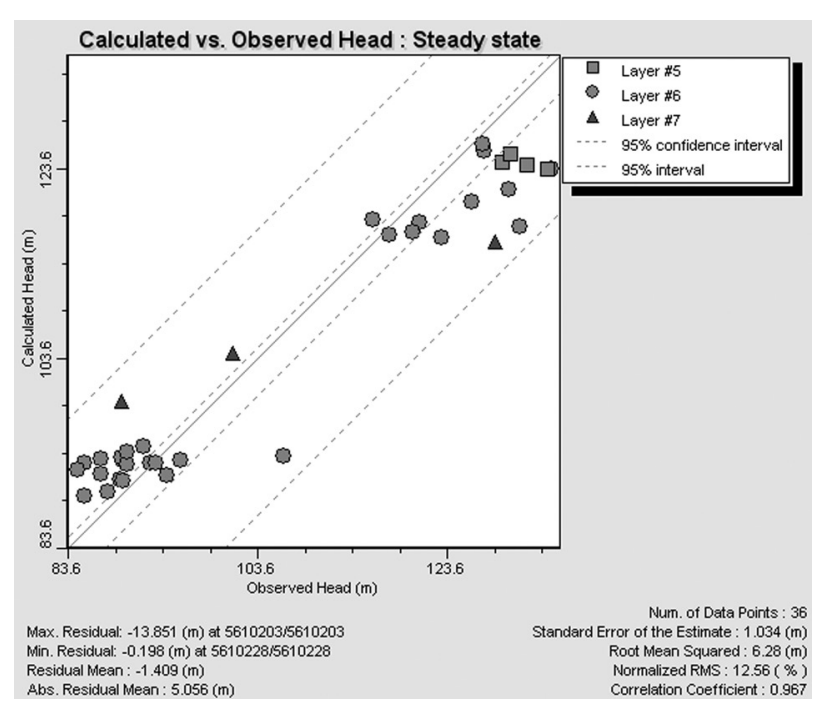

Ryc. 6. Kalibracja modelu numerycznego (okno programu Visual MODFLOW)

Fig. 6. Calibration of numerical model (Visual MODFLOW interface)

W strefie dolinnej analizowanego obszaru zlokalizowanych jest 6 dużych ujęć wód podziemnych o wydajnościach przekraczających $50 \mathrm{~m}^{3} \mathrm{~d}^{-1}$. W ujęciu regionalnym ich eksploatacja nie ma wpływu na generalne kierunki i charakter przepływu wód podziemnych. Odmienna sytuacja występuje w strefie wysoczyznowej. Z uwagi na brak występowania ciągłej, miąższej warstwy wodonośnej eksploatowane są wody z fluwioglacjalnych przewarstwień piaszczystych. Z powodu niskiej przewodności warstwy te charakteryzują się małymi wydajnościami rzędu kilku, kilkunastu $\mathrm{m}^{3} \mathrm{~d}^{-1}$, a ich eksploatacja wiąże się ze znacznym obniżeniem ciśnienia piezometrycznego $\mathrm{w}$ danym przewarstwieniu.

Wody w piaszczystych przewarstwieniach w obrębie utworów morenowych w przeciwieństwie do dolinnych kompleksów wodonośnych cechuje niska wrażliwość na zmiany poziomu wód w ciekach powierzchniowych. Ze względu na ich częściową izolację reakcja na zmiany sum opadów zaznacza się z pewnym opóźnieniem. Nawet krótkotrwały impuls zwiększonych opadów podnieść może ciśnienie w dłuższym okresie. Może to powodować występowanie lokalnych, długotrwałych podtopień i wysięków w kondygnacjach podziemnych głębiej posadowionych budynków oraz w lokalnych obniżeniach powierzchni terenu.

Dotychczasowe prace posłużą do ustalenia prognoz przemieszczania się zanieczyszczeń w wodach podziemnych w rejonie składowiska odpadów komunalnych „SATER Otwock” w miejscowości Glina. Będą one także podstawą do prowadzenia wielowariantowych analiz wpływu zwiększania wydajności istniejących oraz budowy nowych ujęć wód podziemnych w rejonie Otwocka.

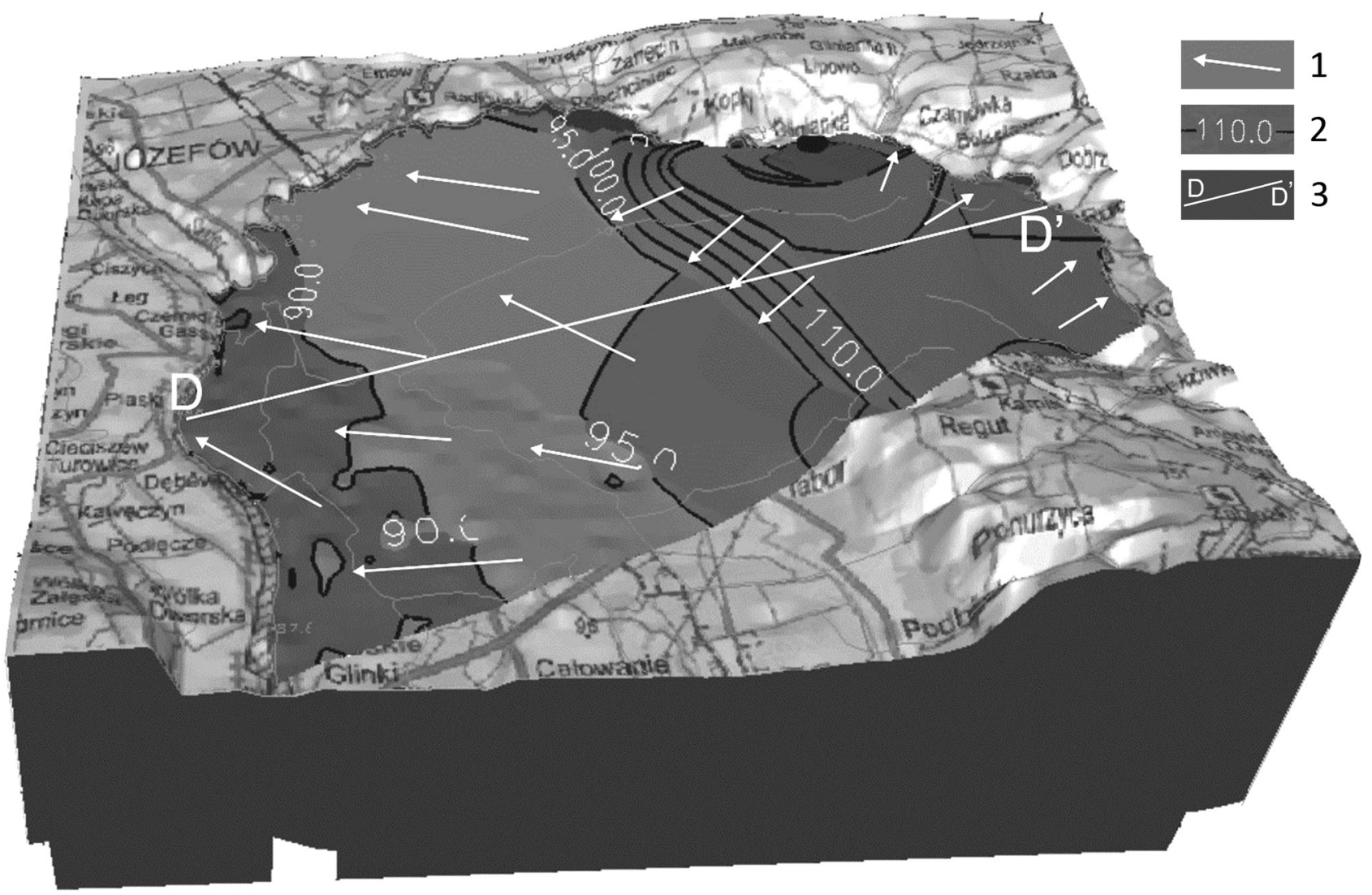

Ryc. 7. Rozkład wysokości hydraulicznej na podstawie badań modelowych

1 - kierunek przepływu wód podziemnych, 2 - hydroizohipsa, 3 - linia przekroju

Fig. 7. Layout of hydraulic pressure on the modeling study

1 - groundwater flow, 2 - hydroizohypse, 3 - cross section 


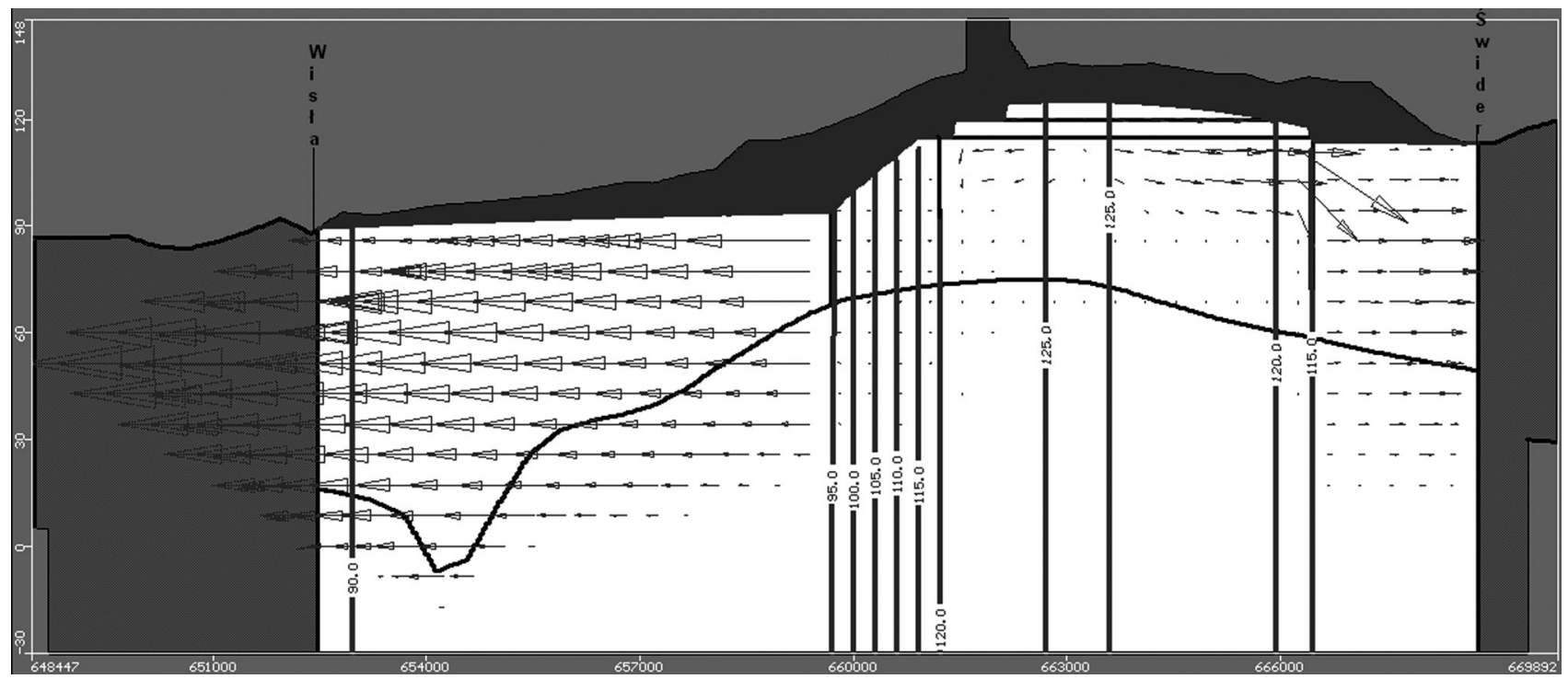

Ryc. 8. Schemat przepływu wód podziemnych w przekroju D-D' (okno programu Visual MODFLOW)

Fig. 8. Schematic diagram of groundwater flow in cross section D-D' (Visual MODFLOW interface)

Bilans krążenia wód modelowanego obszaru zamieszczono w tabeli 1.

\section{Wnioski}

Obecność wypiętrzenia glacitektonicznego w strefie krawędziowej wysoczyzny morenowej wpływa zarówno na regionalne, jak i lokalne warunki krążenia wód podziemnych.

Elewacja Wólki Mlądzkiej stanowi nieprzepuszczalną barierę uniemożliwiającą swobodną wymianę wód pomiędzy kompleksami dolinnymi i warstwami wchodzącymi w skład utworów wysoczyznowych, tworzącą lokalną strukturę wododziałową.

W rejonie występowania przedmiotowego wypiętrzenia zaznacza się znacznie wyższy spadek hydrauliczny pomiędzy utworami doliny a wysoczyzny.

$\mathrm{Z}$ badań modelowych wynika, że w strefie krawędziowej wysoczyzny wody podziemne w piaszczystych przewarstwieniach, nie znajdując swobodnego ujścia w kierunku doliny, ulegają spiętrzeniu i występują znacznie płycej niż w strefach niezaburzonych. W strefie terasy rzecznej przylegającej do skarpy wysoczyzny wody podziemne zalegają głębiej niż w innych niezaburzonych re-

Tabela 1. Bilans wody w modelu

Table 1. Water balance of the model

\begin{tabular}{|c|c|c|c|}
\hline \multicolumn{2}{|l|}{ Przychody $\left[\mathrm{m}^{3} \mathrm{~d}^{-1}\right]$} & \multicolumn{2}{|c|}{ Rozchody $\left[\mathrm{m}^{3} \mathrm{~d}^{-1}\right]$} \\
\hline Infiltracja efektywna & 2305 & Drenaż rzeczny & 80700 \\
\hline $\begin{array}{l}\text { Dopływ podziemny do } \\
\text { południowej i wschodniej } \\
\text { granicy modelu }\end{array}$ & 79490 & $\begin{array}{l}\text { Eksploatacja } \\
\text { ujęciami }\end{array}$ & 7379 \\
\hline $\begin{array}{l}\text { Lokalne zasilanie od rzeki } \\
\text { Świder }\end{array}$ & 5827 & - & - \\
\hline Suma & 87622 & Suma & 88079 \\
\hline \multicolumn{4}{|c|}{ Różnica: $-0,52 \%$} \\
\hline
\end{tabular}

jonach. Jest to efekt braku lateralnego zasilania od strony wysoczyzny.

W ujęciu regionalnym nie odnotowano wpływu ujęć wód podziemnych eksploatowanych w rejonie badań na kierunki i charakter przepływu wód podziemnych.

\section{Podziękowania}

Autorzy dziękują dwóm anonimowym recenzentom za wnikliwe uwagi do wcześniejszej wersji artykułu.

\section{Literatura}

Aber J.S., Ber A., 2007. Glaciotectonism. Developments in Quaternary Science 6. Elsevier.

Baraniecka M.D., 1976. Szczegółowa Mapa Geologiczna Polski w skali 1:50 000. Arkusz Otwock. Wyd. Geol., Warszawa.

Baza, 2014. Centralna Baza Danych Hydrogeologicznych. PIG-PIB. Online 5.02.2014 - http://spdpsh.pgi.gov.pl/PSHv7/.

Brykczyński M., 1982. Glacitektonika krawędziowa w Kotlinie Warszawskiej. Prace Muzeum Ziemi 35, Prace Geologiczne 35(57): 3 -57 .

Falkowski T., 1999. Wyciśnięcia utworów spoistych w strefach krawędziowych dolin rzecznych na Niżu Polskim jako elementy ograniczające kontakt wód podziemnych doliny i wysoczyzny. Współczesne Problemy Hydrogeologii IX.

Kleczkowski A.S., 1990. Mapa obszarów głównych zbiorników wód podziemnych (GZWP) w Polsce wymagających szczególnej ochrony w skali 1:500 000. AGH, Kraków.

Kondracki J., 2001. Geografia regionalna Polski. Wyd. Nauk. PWN, Warszawa.

McDonald M., Herbaugh A., 1988. A modular three-dimensional finite - difference groundwater flow model. Modflow U.S. Geological Survey, Washington.

Malinowski J. (red.), 1991. Budowa geologiczna Polski. T. VII. Hydrogeologia. Wyd. Geol., Warszawa.

Małecki J., Nawalany M., Witczak S., Gruszczyński T., 2006. Wyznaczanie parametrów migracji zanieczyszczeń w ośrodku porowatym dla potrzeb badań hydrogeologicznych i ochrony środowiska. Poradnik metodyczny. Min. Środowiska, Warszawa.

Mianowski Z., 1997. Mapa Hydrogeologiczna Polski w skali 1:50 000. Arkusz Piaseczno. PIG, Warszawa. 
Perek M., 1997. Mapa Hydrogeologiczna Polski w skali 1:50 000. Arkusz Otwock. PIG, Warszawa.

Różycki S.Z., 1972. Plejstocen Polski środkowej na tle przeszłości w późnym trzeciorzędzie. Wyd. Nauk. PWN, Warszawa.

Sarnacka Z., 1976. Szczegółowa Mapa Geologiczna Polski w skali 1:50 000. Arkusz Piaseczno z objaśnieniami. Wyd. Geol., Warszawa.
Złotoszewska-Niedziałek H., 2007. Monitoring of the groundwater environment within a landfill site. Annals of Warsaw Agricultural University of Life Sciences, Land Reclamation 38: 49-56.

Złotoszewska-Niedziałek H., 2012. Wypiętrzenie strukturalne jako bariera geologiczna dla migracji zanieczyszczeń do wód podziemnych w rejonie składowiska odpadów. Acta Scientiarum Polonorum, Architectura 11(1): 49-56. 